\title{
Elite periodicals between propaganda and empowerment
}

\section{Congolese voices}

The Voix du Congolais, the most important newspaper for the Belgian Congo's new elite, was a child of the Second World War. It must be viewed in the context of the propaganda activities pursued by the General Government, based in the capital city of Léopoldville, whose Service de l'Information et de la Radiodiffusion had kept European residents throughout the colony informed about the course of the war since September 1940 and, backing Belgium's exile government, had condemned the German occupation of the country. ${ }^{1}$ In response to the public demands made by educated Congolese, in 1944, under Governor General Pierre Ryckmans, an equivalent department came into being in the shape of the Section de l'Information pour Indigènes, which was incorporated into the Affaires Indigènes et de la Main-d'Oeuvre (AIMO). ${ }^{2}$ This new section was headed by JeanPaul Quix, who had worked in the Congo for 20 years as a territorial official. A former student of philosophy, he was put in charge of a newspaper for the vernacular elite under the aegis of the General Government in Léopoldville. ${ }^{3}$

In October and November 1944 Quix assembled a group made up of Congolese office workers employed in the colonial administrative apparatus and mission school teachers, who declared their objectives to be the "civic education of all Congolese" and the turning of "blacks" into "model citizens." l'Information pour Indigènes was subdivided into the fields of press, radio, cinema and libraries; committees with a president and six members were established

\footnotetext{
1 The following remarks are based on articles in the 10-year anniversary edition of the Voix $d u$ Congolais, in which a number of key actors discuss its establishment; Voix du Congolais no. 106 (January 1955). For a concise overview of the newspaper, see Kadima-Nzuji, Littérature, 40 - 43; J. C. Ekabmo, “La Voix du Congolais s'est éteinte," Le Phare, 21 October 2010, www.lephareonline.net/la-voix-sest-eteinte/ (1 May 2015).

2 This department was the Congolese counterpart to the Service de l'Information et de la Radiodiffusion. Headed by Carl Goebel, in 1942 it was renamed the Service de l'Information et de la Propaganda. See A. Cornet and F. Gillet, Congo-Belgique, 1955-1965. Entre propagande et réalité (Brussels: Renaissance du Livre, 2010), 8; self-description of the Service de l'Information et de la Propaganda du Congo Belge, 31 December 1943, AA/GG/5403.

3 On Quix's career, see J. Burlion, “J. P. Quix,” in Biographie Belge d'Outre-Mer, vol. 7-B, ed. Académie Royale des Sciences d'Outre-Mer (Brussels: Librairie Falk fils, 1977).

4 “Activités des Comités d'Information de Léopoldville," Voix du Congolais no. 1, (January-February 1945): 17-21, 17.
}

Ә OpenAccess. () 2021 Daniel Tödt, published by De Gruyter. (cc) BY This work is licensed under the Creative Commons Attribution 4.0 International License. https://doi.org/10.1515/9783110709308-003 
for each of these. At the first meeting, Antoine-Roger Bolamba, an African employee of the General Government with journalistic experience, had already underlined his leading role by giving a speech of welcome, and he was made head of the press committee. Given the wartime lack of resources this committee initially rejected a proposal to found a daily and weekly newspaper. Instead, it resolved to develop a "monthly newspaper for French-speaking blacks and a magazine for uneducated Congolese." 5 The Voix $d u$ Congolais, aimed at a Francophone readership, appeared in January 1945, initially in a 32-page edition, while the magazine, for those unable to read, was first published in 1947 under the name Nos Images.

The Voix du Congolais featured opinion pieces, short articles, reportage, information on cultural and social affairs, news of associations, reports from the colony and occasionally from across the world, but also poems, photo series, readers' letters and illustrations. Flicking through this newspaper gives one a sense of what the évolués' concerns were, how they commented upon events and developments in their country, how they interpreted their place within colonial society, what their demands were and how they saw their future.

In Léopoldville, the editorial team moved into an office on the Avenue Baudouin, the capital's main connecting road, between the new Congolese residential district and the European town centre. A sign reading La Voix du Congolais, mounted on the building's projecting roof, was an advertisement for the newspaper but also an attempt to bolster the image of the colonial government, which now pledged to listen to the Congolese.

The motto of the Voix du Congolais, "By Congolese, For Congolese," suggested a genuinely Congolese medium. The first issue included the minutes of the founding meetings, illustrated by a group photograph of the committee members, which may in part have been an attempt to convince readers of the credibility of the newspaper's motto. Readers were also informed that the motto was supposed to apply to literally every educated Congolese. Among the newspaper's founding actors, the General Government's close cooperation with Catholic missions on schooling had earlier thrown up the question of whether the authorities would tolerate graduates of Protestant mission schools on the editorial team. The assurance given by the Section de l'Information pour Indigènes that it would refrain from any form of "religious politics" was lent weight by the subsequent nomination of Protestant vice-presidents to every committee. ${ }^{6}$ The Voix $d u$ Congolais was thus conceptualized as the medium of a cross-confessional educated

5 Ibid., 18.

6 Ibid., 17. 


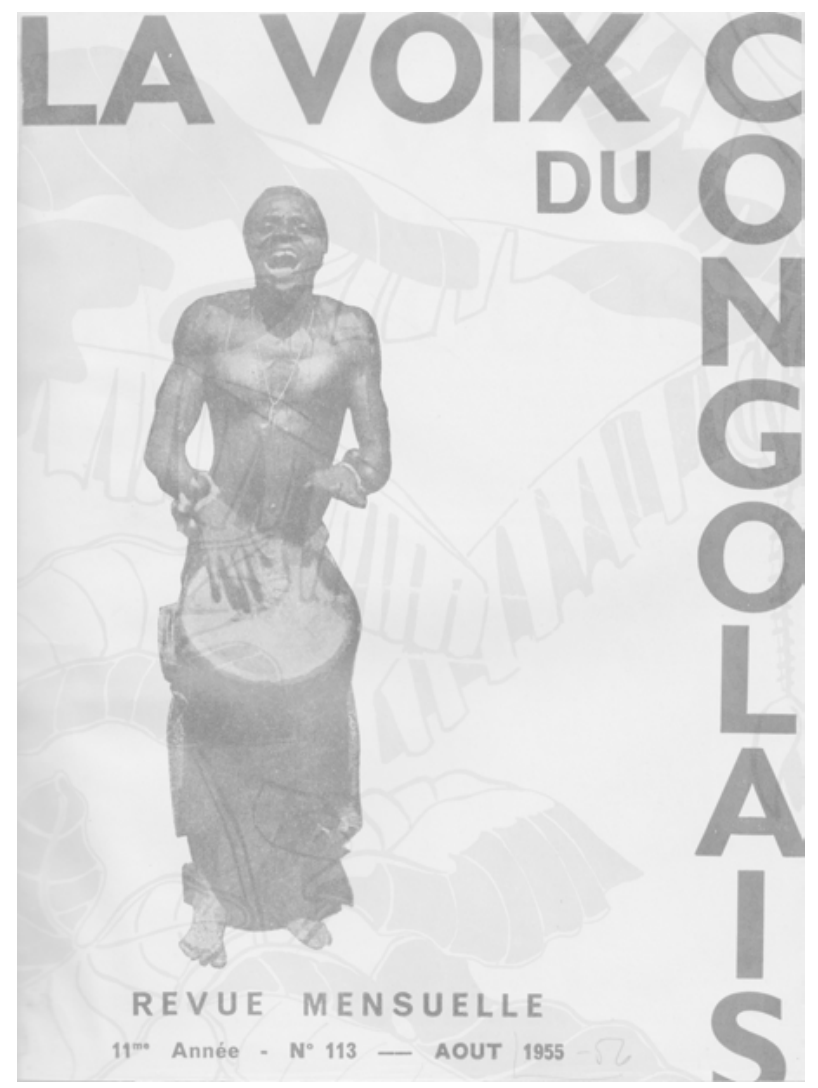

Fig. 4: The cover of the Voix du Congolais.

elite that was to take shape through a process of media-based socialization. The newspaper addressed itself to graduates of secondary mission schools, from which women were excluded by the colonial education system, so it was the voice of Congolese men only. The colonial state provided the évolués with an exclusively male public sphere through media and associations, while the bourgeois gendered order it propagated kept women tied to household and family. ${ }^{7}$

7 On the gender-based realms of the bourgeois public sphere, see Frevert, Frauen-Geschichte, 35; U. Frevert, "Bürgerliche Meisterdenker und das Geschlechterverhältnis: Konzepte, Erfahrungen, Visionen an der Wende vom 18. zum 19. Jahrhundert," in Bürgerinnen und Bürger. Geschlechterverhältnisse im 19. Jahrhundert, ed. U. Frevert (Göttingen: Vandenhoeck \& Ruprecht, 1988). For an account that sounds out the transitions between private and public spaces, see Budde, "Geschlechtergeschichte." 


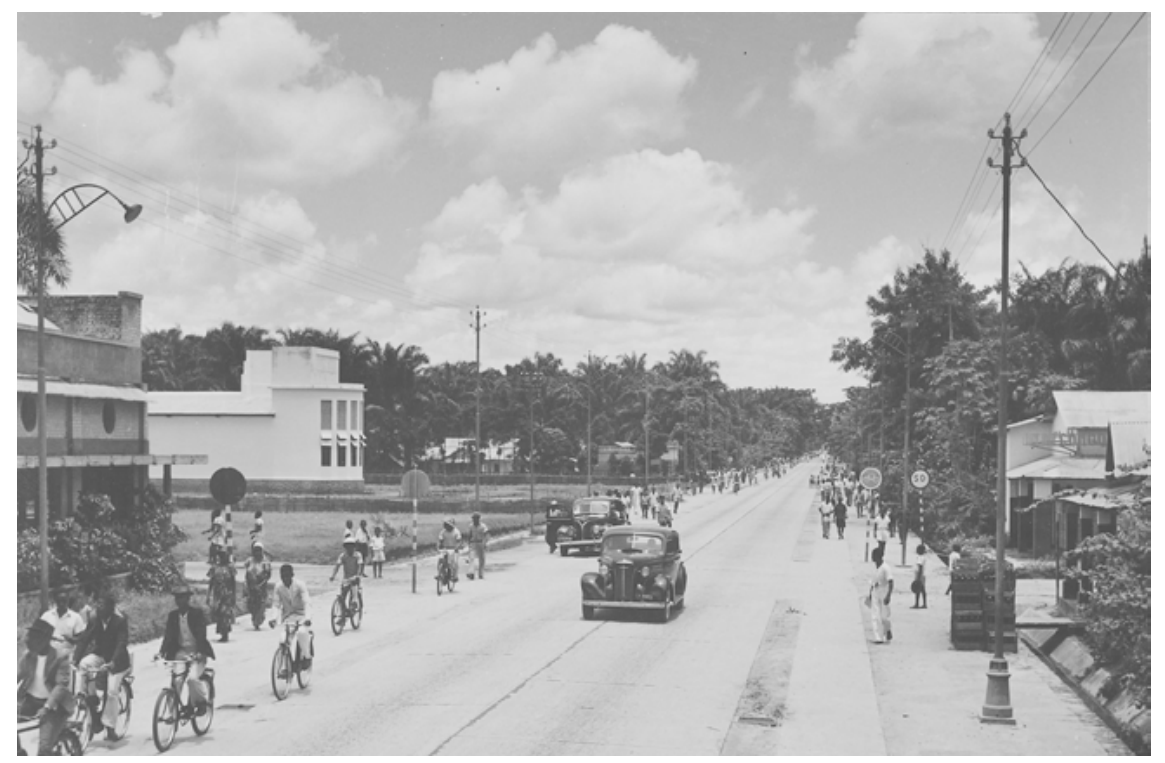

Fig. 5: The Avenue Baudouin amid afternoon traffic flows, 1947. On the left the building of the foyer social, on the right the editorial offices of the Voix du Congolais.

But it was not just readers that the General Government had to persuade but also future staff members. The minutes of the committee meetings say nothing about the initial lack of trust felt by the Congolese members of the editorial team regarding the colonial state's patronage of the Voix $d u$ Congolais. Joseph Davier, founding member and graduate of a Catholic mission school that trained for positions in the colonial administration, later recalled that those invited to participate initially suspected that the General Government's initiative was an attempt to identify critical individuals with the help of the newspaper. ${ }^{8}$ According to him all those present were aware that criticism of the Belgian authorities could result in severe punishment. Banishment to remote regions of the hinterland and a flogging with a hippopotamus-hide whip were among the most feared. ${ }^{9}$ Clearly, against this background it took courage for Congolese to get involved in this media pilot project. Yet for these authors it held out the prospect of participating, as responsible citizens, in debates on post-war Congo and of making their voices heard.

8 J. Davier, “Souvenirs d'anniversaire,” Voix du Congolais no. 106 (January 1955): 8.

9 Ibid. 
The columns of the Voix du Congolais were penned not just by the editorial staff in Léopoldville but by Congolese writers from throughout the colonial territory. Some authors, however, complained about the lack of local news. In view of the large number of reports concerning Léopoldville, this fuelled the impression that the newspaper was only by and for évolués in the capital. The colonial government responded to this critique and added publications with a regional focus to the state-sponsored press landscape. Newspapers such as the Coquilhatville-based Mbandaka were popular among the local évolués. ${ }^{10}$ The relative independence of the economically important region of Katanga, meanwhile, was apparent in the foundation of the monthly newspaper L'EtoileNyota. This was published by the AIMO of the provincial government in Elisabethville under the leadership of a former editor of the conservative Essor $d u$ Congo, a publication aimed at a European readership. The Etoile-Nyota resembled the Voix $d u$ Congolais in its didactic style. It printed articles about the évolués' associations in Katanga but also sought to appeal to the less educated workers employed in local industries. Nonetheless, the Voix $d u$ Congolais remained the leading voice for the educated elite throughout the Belgian Congo.

The aspiration of the Voix $d u$ Congolais to be a newspaper for all Congolese was a logistical challenge given the colonial territory's geography and infrastructure. From Léopoldville the postal service distributed the newspaper far into the hinterland, by aeroplane, boat, train and automobile. The authorities made a conscious effort to provide associations of évolués and individual évolué subscribers with the latest edition. Particularly in remote areas, however, deliveries were often unreliable, prompting some readers who had already paid an annual fee in advance to cancel their subscription in frustration. ${ }^{11}$ In a territory half the size of Western Europe whose infrastructure was only now being developed, the second issue of the Voix du Congolais could present it as a success that 700 Congolese and a number of Europeans had taken out subscriptions, while several hundred individual copies of each edition had been sold. By the end of 1947 the number of subscribers had risen to 2,200. ${ }^{12}$ Over the course of the 1950s the monthly print run levelled off at 4,700 copies, so that the Voix du Congolais

10 On Mbandaka's network of correspondents and on its sales and distribution, see AA/GG/ 7755.

11 Letter to the territorial administrator of Inongo, 1 October 1956, AA/GG/15611.

12 Chambre des représentants, Rapport sur l'administration de la colonie du Congo Belge pendant l'année 1947 présenté aux Chambres Législatives (Brussels: Ministere des affaires africaines, 1948), 15. There are no documents that might allow us to deduce annual trends in numbers of subscribers. 
remained an elite product; five times as many copies of Nos Images, which was aimed at an uneducated readership, were published. ${ }^{13}$

The General Government got its administrative officials involved in the newspaper's sales and distribution and frequently required them to promote it. The various provincial governors, meanwhile, kept records of the subscriptions obtained within a given year and passed them on to Léopoldville. The General Government issued special guidelines for the newspaper's distribution. In each urban administrative unit, for example, at least one issue of the Voix $d u$ Congolais had to be made available for every 300 families. Relative to the monthly wage of the target group, that is, the educated and employed Congolese elite, the General Government considered the purchase price socially acceptable. The colonial state assumed that the newspaper would have to be subsidized; the revenue raised was merely supposed to cover production costs. ${ }^{14}$ The distribution targets, however, were barely achieved. The provincial governors, who had to account for the subscription figures to the colonial government, often criticized the inadequate promotional work done by their subordinate officials. While some territorial officials failed to attract any new subscribers, others managed to do so by obliging Congolese office workers to tout the newspaper within their circle of acquaintances. ${ }^{15}$ In addition, in order to increase readers' engagement, the newspaper introduced an annual contest to achieve the largest number of new subscribers. A portrait photograph of the winner was printed in the newspaper. The best results were attained by Congolese clerks, who were awarded a bicycle, typewriter or subscription. ${ }^{16}$

A progress report by Alphonse Salongo from Stanleyville sheds some light on the difficulties involved in acquiring subscribers. Initially, given the existence of "thousands of young intellectuals," which meant school leavers with the ability to read, he had drawn up a list of 150 individuals who might be interested, whom he then visited at home or at their place of work. ${ }^{17}$ If some of the potential subscribers were unable to pay sixty francs for an annual subscription, Salongo

13 Centre de Recherche et d'Information Socio-Politiques, "La presse quotidienne au Congo," Courrier hebdomadaire du CRISP 26 (1959).

14 Letter from the governor of Équateur province to the territorial administrators, 3 May 1956, AA/GG/20535.

15 Letter from the territorial administrator in Gemena to Congolese office workers, 22 May 1956, AA/GG/8079.

16 "Résultats du grand concours de propagande 1951," Voix du Congolais no. 62 (May 1951): 286; “Résultats du grand concours de propagande 1949," Voix du Congolais no. 37 (April 1949): 133. 17 A. Songolo, "Réflexions d'un propagandiste de La Voix du Congolais," Voix du Congolais no. 65 (August 1951): 443. 
sought them out on payday. He presented himself as a relentless and incessant promoter who combed through bars and residential buildings in his spare time looking for customers. The way in which Salongo interpreted the lack of interest of his target group reflects the self-image of the Voix $d u$ Congolais as a vehicle for the forging of a Congolese elite. As he saw it only the newspaper's readers were members of this elite. For Salongo lack of interest or unwillingness to pay the subscription fee were evidence of an immoral lifestyle in which alcohol was more important than education and family. Salongo was recognized as the second-best advertiser of 1950, his prize "an excellent bicycle.” Later, however, he related, his customers demanded a reward for their help in the shape of two crates of beer or shared use of the bicycle. The chief editor of the newspaper praised Salongo's efforts and complained about the ignorant évolués, who showed little inclination to help shape the future of the Congo. ${ }^{18}$

Distrust of a newspaper spawned by the colonial government, irregular deliveries and other consumption priorities: there were a number of reasons for the problems suffered by the Voix $d u$ Congolais as it sought to win over its target group. Another was undoubtedly the accessibility of its texts in terms of both content and language. The newspaper presented itself as an emphatically elite organ. Its articles, all of which were in French, presupposed an advanced level of schooling. ${ }^{19}$ Seminary graduates writing for the paper came across as particularly bookish with their Latin phrases and philosophical treatises. The layout was highly formal, the flow of text leavened by just a few pictures. The authors' obvious attempts to demonstrate their eloquence and education through highbrow and unusual language made the newspaper a demanding read, one aimed explicitly at the "elite of the indigenous society."20

The state of the sources does not allow us to make empirically reliable statements about how widely distributed and well known the Voix du Congolais actually was among its target group. But we can gain some insight - in the form of a random sample - from a survey carried out by a Catholic missionary of the Scheut order in the newspaper's first year of publication in Kabinda, an

18 Ibid., 446-447.

19 A short report in Lingala, a lingua franca in the Belgian Congo disseminated by the Force Publique, which advanced to the status of official national language following independence, was first published in 1957; J. Koy, "Sango na Yahuma," Voix du Congolais no. 139 (October 1957): $800-801$. This prompted a number of readers to send in letters demanding a return to a French-only publication. For them, a newspaper for the elite ought to be in French; N. Mpako, “Une opinion,” Voix du Congolais no. 142 (January 1958): 79.

20 “Sommaire," Voix du Congolais no. 40 (July 1949): 258. 
urban settlement in Kasai Province. ${ }^{21}$ Of the 47 "office workers and other évolués" who were questioned, just 11 had heard about the publication of the first two issues, and of the total of 8 readers only half indicated that they had understood the content. ${ }^{22}$ In order not to permanently put off potential readers through the newspaper's high linguistic level, in 1947 the Section de l'Information pour Indigènes began to send articles written in a generally understandable way from the Voix du Congolais and other media specifically to territorial administrators and the patrons of elite institutions. These so-called "articles for Congolese" were intended to serve association members as a basis for their own talks or for group discussions and they were allowed to reproduce them free of charge. ${ }^{23}$ Topics such as "Sunday joys" and "fashion, personal grooming and good taste" imparted notions of morality and tips on everyday behaviour. ${ }^{24}$ Hence, while the level of sophistication was sometimes dialled down for the associations, the Voix $d u$ Congolais remained a medium for educated Congolese with a desire for knowledge, who could reassure themselves of their elite education by reading the publication and helping to edit it.

The founding and reception of the Voix du Congolais must be interpreted in the context of the colonial reforms implemented towards the end of the Second World War. The newspaper was a component in the colonial state's elite-making project. ${ }^{25}$ It constituted a public sphere through which the country's colonial elite, the évolués, could be addressed and talk to one another and it provided them with unprecedented opportunities for journalistic activity. It also represented a medium that allowed the colonial government to communicate its interests and to win over the Congolese elite to Belgian post-war developmental colonialism. ${ }^{26}$ The Voix $d u$ Congolais made announcements about the progress of the Ten-Year Plan and reported on improvements in everyday lives. For example, articles provided information on the expansion of medical facilities, while photo series showed major construction sites, apparently soon to be transformed

21 Letter to Georges Six, provincial bishop of Léopoldville, 3 March 1945, KADOC/O/II/b/9/5. 22 Ibid.

23 Letter from the provincial governor in Coquilhatville to the district commissioner of Tshuapa, 26 February 1946, AA/GG/5991. Later entire series of such articles were sent out in single batches, AA/GG/10384.

24 Ibid.

25 On government-owned periodicals and settler newspapers in relation to African intermediaries and colonial public spheres in West and East Africa, see E. Hunter, “'Our common humanity': print, power, and the colonial press in interwar Tanganyika and French Cameroun,” Journal of Global History 7 (2012).

26 On the history of colonial propaganda in the Belgian Congo, see Cornet and Gillet, CongoBelgique. On colonial propaganda in Belgium, see Stanard, Selling. 
into hospitals, schools, factories and new residential areas. These semantic and visual depictions of the Belgian Congo set out to persuade rather than to inform. First and foremost, they imparted the success story of the allegedly model colony. The propagandistic messages were intended to "trigger a specific perception of events or opinions" on the part of the target group, ${ }^{27}$ a perception geared towards the core elements of colonial ideology and politics.

But the newspaper propagated the reformist intent of Belgian colonialism not just to the évolués but also to the critical international community. This was a publication that reflected the colonial rulers' desire for prestige; they were less concerned about its linguistic accessibility than with the image it conveyed of their overseas possession.

In a sense, the elite language used in the Voix $d u$ Congolais made it the poster child for Belgian colonial policy: the newspaper was intended to demonstrate to the outside world the successes of the Belgian Congo's schools, which had been criticized as inadequate. Praise was soon to be heard in the United States, from the chief editor of The Crisis, a periodical founded by W. E. B. Du Bois in 1910, published by the National Association for the Advancement of Colored People (NAACP) and dedicated to the integration of African Americans through education. In the Voix du Congolais, The Crisis glimpsed the "product of intelligence and an indigenous pen,"28 testimony to the Belgians' civilizational influence in the Congo. But critical voices were also to be heard. The US-American consul general in Léopoldville was not convinced by the newspaper. Given that the colonial government had shown such a lack of interest in the affairs of educated Congolese for so many years, he interpreted the publication of an elite periodical - against the background of the pending UN founding conference - as a transparent "attempt, at the last minute, to demonstrate a more liberal stance towards the indigenous population. ${ }^{29}$

A voice for the Congolese elite, published by the colony's General Government: it is hardly surprising that actors critical of colonialism viewed the Voix

27 T. Bussemer, “Propaganda. Theoretisches Konzept und geschichtliche Bedeutung,” Docupedia-Zeitgeschichte, accessed February 4, 2021, doi.org/10.14765/zzf.dok.2.239.v1. On the definition of the problematic concept of propaganda and suggestions, taken up in the present book, on how we might operationalize it in studies of a cultural-historical nature, see Bussemer, "Propaganda”; R. Gries, "Zur Ästhetik und Architektur von Propagemen. Überlegungen zu einer Propagandageschichte als Kulturgeschichte,” in Kultur der Propaganda, eds. R. Gries and W. Schmale (Bochum: Winkler, 2005).

28 A.-R. Bolamba, "Une année historique," Voix du Congolais no. 7 (January-February 1946): 243.

29 Quoted in Mollin, USA und der Kolonialismus, 141. 
$d u$ Congolais with scepticism. In particular, pan-Africanist and Marxist intellectuals, who came together in Paris after 1945 much as they had done in the inter-war period, ${ }^{30}$ doubted the sincerity of the newspaper's goals. The newspaper Présence Africaine had been founded in the French capital in 1947 by Alouine Diop, a Senegalese member of the French Senate and university professor. Its first issue cited the Voix $d u$ Congolais as an example of a new wave of trivial and paternalistic publications in the colonial world. ${ }^{31}$ For the Présence Africaine the Voix du Congolais was the polar opposite of its free-thinking approach and critique of colonialism. The newspaper from Léopoldville did in fact seem provincial and anachronistic when compared with Présence Africaine, ${ }^{32}$ which carried articles by renowned intellectuals from all over the world such as Jean Paul Sartre, Georges Balandier, Léopold Sédar Senghor and Richard Wright. In his review of the Voix du Congolais, philosophy teacher Jacques Howlett cast doubt on the authors' freedom of expression. ${ }^{33}$ He quoted the text accompanying a photograph in the Congolese publication: "A fine group of évolués in Léopoldville." To him this was evidence enough that in this newspaper the évolués were objects rather than subjects. He concluded his scathing review with a sarcastic suggestion for an alternative caption: "A wall, a fig tree, a plant, an évolué." ${ }^{4}$

30 On this milieu after 1945, see A. Eckert, "Das Paris der Afrikaner und die Erfindung der Négritude,” Themenportal Europäische Geschichte (2007), http://www.europa.clio-online.de/2007/ Article=111 (24 January 2021); J. Riesz, Léopold Sédar Senghor und der afrikanische Aufbruch ins 20. Jahrhundert (Wuppertal: Peter Hammer, 2006); L. Heerten, "Léopold Sédar Senghor als Subjekt der 'Dialektik des Kolonialismus.' Ein Denker Afrikas und die imperiale Metropole,” Stichproben. Wiener Zeitschrift für kritische Afrikastudien 15 (2008). On its forerunners in the inter-war period, see M. Goebel, Anti-Imperial Metropolis.

31 J. Howlett, "La Revue des Revues," Présence Africaine no. 1 (1947): 179.

32 The periodicals in the Belgian Congo differ markedly from some of the critical or openly anticolonial African-owned newspapers in parts of West and East Africa. On the history of newspapers in the Gold Coast since the mid-nineteenth century, see, A. Gadzekpo, "Gender Discourse and Representational Practices in Gold Coast Newspapers," Jenda: A Journal of Culture and African Women Studies 1, no. 2 (2001); Newell, "How to Play”; Plageman, Accra. On the radical press in Nigeria with an international audience, see O. Coates, "'His telegrams appear to be hysterical, but he is very astute: Azikiwe's spectacular self and the 1945 General Strike in Nigeria," Journal of African Cultural Studies 30, no. 3 (2018). On East Africa, see J.F. Scotton, "The first African press in East Africa: Protest and Nationalism in Uganda in the 1920s," The International Journal of African Historical Studies 6 (1973).

33 Ibid.; on the role of Jacques Howlett in Présence Africaine, see V. Y. Mudimbe, eds., The Surreptitious Speech. Présence Africaine and the Politics of Otherness (Chicago: University of Chicago Press, 1992), 369-371.

34 Howlett, "La Revue des Revues," 179. 
These contemporary perspectives from outside certainly capture the field of tension within which the Voix $d u$ Congolais operated - between the propaganda of the colonial state and the participation of Congolese in society. But in reality, how strong a position did colonial policy grant to the vernacular elite within the media and public sphere?

The critique articulated at the international level saw the Voix $d u$ Congolais as a strategic move by the architects of Belgian colonial policy, one intended to enhance its standing within the international system. In particular, doubters questioned whether Congolese authors could use the newspaper to make their voices heard or express criticism. Yet these appraisals failed to grasp the heterogeneity and complexity of the colonial situation in the Belgian Congo. First, a greater number of actors were involved than implied by the dichotomous notion of colonizers and colonized. Furthermore, within the institutions of the colonial state having a say and propaganda were not necessarily mutually exclusive concepts. Instead, they entered into ambivalent fusions. In a seeming paradox, the Congolese authors' agency began the moment they accepted the colonial government's promises of change and demanded that it make good on them. Belgian reformist propaganda could placate the UN with its critique of colonialism, but this stirred up the feelings and expectations of the elite. It is crucial, then, to go beyond an examination of the colonial propaganda produced by the Voix $d u$ Congolais solely from the perspective of the indoctrination and manipulation of this elite. We also have to scrutinize the new scope for articulation and room for manoeuvre that the newspaper opened up to them. Educated Congolese were not passive readers but active authors. ${ }^{35}$ Unable to foresee the consequences of doing so, through the new elite's key medium the colonial state laid the ground for a contentious debate on the future of the Belgian Congo.

\section{The print media of the Catholic missionary orders}

The early press landscape of colonial Africa was the work of missions. Not just in the Belgian Congo but in other colonies as well it was missionaries that taught Africans to read and write and acquainted them with a textual culture. For these missionaries, reading the Bible was tantamount to a direct dialogue with God and they often involved converts who had learned to write in the production

35 Here I adhere to a conception of propaganda in which "propaganda-based communication [is] understood to entail active complicity between propagandists and recipients, in the process of which meanings are negotiated and recalibrated." T. Bussemer, "Propaganda," 11; see also Gries, “Zur Ästhetik,” 19-21. 
of short texts, newspapers and even novels. ${ }^{36}$ As a key instrument of the colonial state's elite-making, the Voix du Congolais entered a media realm that the Catholic missions had already created in rudimentary form in the 1920s. Through occasional newspapers the Catholic missionary orders had addressed themselves to the graduates of their secondary schools. In Belgium too, during the interwar period an ideologically differentiated confessional press landscape had become established within the framework of Catholic Action. In addition to intellectual and literary reviews this encompassed many newspapers launched by Catholic reading groups, youth associations, women's associations, schools and universities. ${ }^{37}$ While the mission-based press landscape in the Belgian Congo was relatively small, its relationship with the Voix du Congolais is instructive. A conflict gradually emerged between the missions and the colonial state, centred on who ought to be entrusted with the task of educating the Congolese elite.

At first glance it is easy to discern continuities between the Voix du Congolais and the established missionary press. It is no coincidence that the newspaper resembled Signum Fidei in its professed goal of forging the educated Congolese scattered across the colonial territory into a community of readers. ${ }^{38}$ Signum Fidei had been founded in 1929 as an "organ for the former pupils of the Christian schools in the Congo" by the Frères des écoles chrétiennes, a Catholic missionary order that, following its emergence in 1684 in northern France, rapidly gained a foothold in what is now Belgian territory, where it provided free schooling. In 1909 the Belgian colonial state had put this missionary order in charge of the Colonie Scolaire in Boma, a port city in western Congo and its capital at the time. ${ }^{39}$ In its first few years its Congolese pupils were chiefly recruited as soldiers for the Force Publique, but in the inter-war period the Colonie Scolaire increasingly began to train its charges for office work within the administrative system. The

36 On the nexus of mission, conversion and literacy in Africa, see Newell, Game of Life, 83-97. On the case of South Africa, whose press history began with missionary publications as early as 1830, see L. Switzer, “Introduction. South Africa's Alternative Press in Perspective," in South Africa's Alternative Press. Voices of Protest and Resistance, ed. L. Switzer (Cambridge: Cambridge University Press, 1997). On the influence of missionaries on the dissemination of literacy in the German colonies, see L. H. Gann and P. Duignan, eds., The Rulers of German Africa 1884-1914 (Stanford: Stanford University Press, 1977), 208.

37 C. Vanderpelen-Diagre, Écrire en Belgique sous le regard de Dieu. La littérature catholique belge dans l'entre deux guerres (Brussels: Complexe, 2004), 18.

38 The following remarks are based on the perusal of issues of Signum Fidei from 1933, 1935 to 1940, 1947, and 1952 to 1954.

39 See A. Bavuidinsi Matondo, Le système scolaire au Congo-Kinshasa. De la centralisation bureaucratique à l'autonomie des services (Paris: L'Harmattan, 2012). 
Signum Fidei newspaper provided graduates of this mission school with a journalistic home and, with its commitment to Catholic Action, safeguarded their links with the Catholic missionary milieu. The Voix du Congolais resembled Signum Fidei in a number of respects: layout and sections, content, didactic articles offering advice on correct behaviour, and a tendency to propagate desirable recreational activities such as team sports. In addition, Signum Fidei had already explicitly addressed its readers as an "elite," very much in accord with the process of elite formation unfolding within the context of the colonial state's postwar reforms.

But there were also parallels at the level of personnel. The editorial team of the Voix $d u$ Congolais featured many permanent employees who had been educated at the Colonie Scolaire in Boma or at other secondary schools run by the Frères des écoles chrétiennes and who had then found work in the colonial administration in Léopoldville. One prominent example is the aforementioned chief editor Antoine-Roger Bolamba. In the 1930s Signum Fidei published his poems, articles about individuals and obituaries. As the winner of a literary contest organized for Congolese in 1939, he had made a name for himself within the European colonial milieu. His stories subsequently even appeared in Brousse, a cultural periodical with a European readership published under the patronage of the General Government. ${ }^{40}$ Jean-Marie Domont, who replaced Jean-Paul Quix as the newspaper's European patron in the summer of 1946 after illness had prompted him to resign, had also attended one of the schools operated by the Frères des écoles chrétiennes in the Belgian city of Namur. Prior to his work for the Voix du Congolais, Domont had been a territorial official in Boma, home to the Colonie Scolaire, from which many members of the newspaper's staff had been recruited..$^{41}$

The Voix du Congolais faced a direct competitor in the shape of the Croix $d u$ Congo, a weekly newspaper established in Léopoldville in 1932 that was run by the other important missionary society in the Belgian Congo, the Scheut mission. This Roman Catholic male order, which was founded in 1862 near the Belgian

40 Bolamba won with the story "Les aventures de Ngoy, héro légendaire des Bangala," about a Congolese servant of Europeans. It was published in 1940, chapter by chapter, in Brousse. A number of short stories by the same author also appeared after 1945. A.-R. Bolamba, "Le singe de caméléon," Brousse no. 3-4 (1947); A.-R. Bolamba, "Un fils qui voulait être plus malin que son père," Brousse no. 3-4 (1949): 25-26.

41 On Jean-Marie Domont's career in the colonial administration, see A. Lafarge Bembika, Sur les pas de pionniers bâtisseurs. Centenaire de l'établissement des frères des écoles chrétiennes au Congo 1909-2009 (Kinshasa: Fréres des Écoles Chrétiennes, 2009), 102; “Chronique de la vie indigene et nouvelles diverses,” Voix du Congolais no. 15 (May-June 1947): 666-667. 
capital and saw its mission as global in character, had established itself in the Congo Free State at the request of Belgian King Leopold II, its goal being to convert and educate Congolese children in mission schools. Initially, the Scheutists had run the aforementioned Colonie Scolaire in Boma. But when the Belgian state took over the colony in 1908 it put the Frères des écoles chrétiennes in charge to mark a new beginning. This also instigated the latent rivalry between the two leading Catholic missionary orders, which found reflection in parallel educational institutions for Congolese that encompassed both secondary schools and recreational establishments.

The Croix du Congo was a media expression of the attempt by missionaries of the Scheut order to integrate graduates of their schools into Catholic Action. As a "Congolese weekly" the Croix du Congo was headquartered at the Church of Saint Pierre in Léopoldville. ${ }^{42}$ As a French-speaking journal it addressed itself to literate Congolese and mainly provided information on the activities of the Catholic establishments run by the Scheut order. ${ }^{43}$ Pervaded as it was by Christian semantics and symbolism, however, the newspaper also printed news from all over the world. It reported on the latest doings of former pupils, their associations, everyday lives and careers. The Croix du Congo was a medium for former pupils of the Scheut mission schools, who made contributions as authors from every corner of the colony. The articles often struck an edifying or didactic tone and sought to impart the values and lifestyle propagated by the mission schools as part of a Christian life. Photographs displayed and promoted monogamous marriage, church weddings and wage labour, which supposedly guaranteed a life pervaded by bourgeois culture, centred on a home of one's own and a nuclear family. The newspaper's objectives were geared towards those of Catholic Action, in other words it sought to turn its readers and authors, as former mission school pupils, into apostles of everyday life who would advance the evangelization of Congolese society and spread Christian morality within their immediate environment.

The Voix du Congolais placed a question mark over the monopoly enjoyed by the Croix du Congo as the francophone voice and information source for educated Congolese. On a superordinate level this newspaper, so close to the colonial state, signalled to the Scheut missionaries the end of their dominance within post-school elite-making. The missionaries' new prospect was reinforced in the wake of shifts of political power in Belgium immediately after the Second World War: after many years of the pre-eminence of the Parti Catholique, the Lib-

42 Croix du Congo, 11 February 1934.

43 The following remarks are based on perusal of random samples of the Croix du Congo from the 1934 to 1945 period. 
erals took over the colonial ministry in 1945 once again. Representatives of Catholic Action smarted at the loss of their political allies in Brussels. The introduction of the first state schools and the provision of subsidies for Protestant schools, as initiated by Liberal colonial minister Robert Godding, awoke fears that the cultural struggles over the confessionally-based school system might flare up again in both metropole and colony. As the flagship of the colonial state's elite-making, the Voix du Congolais put the Catholic missionaries in a tight spot.

In the Croix du Congo, we can discern these pressures by reading between the lines. Shortly after the appearance of the Voix $d u$ Congolais an editorial in the Croix du Congo welcomed the new newspaper in a spirit of goodwill. In addition to its layout the editorial praised the prospect of the elite of the Belgian Congo being able to put their concerns to the authorities openly. ${ }^{44}$ The editorial concluded, however, by pointing out that the Croix du Congo had already provided Congolese authors with a forum for years. It evoked its dazzling record of printing hundreds of articles by "evolved blacks." 45 The Croix $d u$ Congo rapidly adapted to competition with the Voix du Congolais. By the end of 1945 it had modified its masthead by adding the slogan "the newspaper of the Congolese évolués." It devoted more column inches to reports and commentaries on social affairs in the colony. It also took up discussion topics found in the Voix du Congolais and printed guest articles by staff from the rival publication, such as Bolamba. ${ }^{46}$ The Croix $d u$ Congo was by no means rendered superfluous by the Voix $d u$ Congolais - in 1952 it enjoyed a print run of 5,500 per edition, growing to 8,000 in $1956 .{ }^{47}$

Hence, basing ourselves solely on the print media we might conclude that the Croix du Congo made a tacit arrangement with the new situation. But if we examine correspondence between actors within the Scheut mission we find that they felt pressured by the colonial state's elite-making within the media field. Because the Voix du Congolais recruited its editorial team chiefly from among graduates of the establishments run by the Frères des écoles chrétiennes, institutions close to the colonial state, the Scheutists found themselves falling behind their missionary competitors. Furthermore, the Croix du Congo was worried that it might lose both readers and authors. This aspect weighed all the more heavily due to the broad resonance enjoyed by the Voix du Congolais: it presented itself as cross-confessional and was independent of the church. The new pub-

44 N.n., "La Voix du Congolais," Croix du Congo (4 February 1945).

45 Ibid.

46 A.-R. Bolamba, "Silhouette Indigène," Croix du Congo (4 February 1945).

47 Report on the extramural activities of the Scheut mission in Léopoldville, 1952, KADOC/Z/III/ d/2/7; correspondence on the Croix du Congo (20 December 1956), KADOC/G/XIII/b/4/2. 
lication addressed its educated authors and readers not as the alumni and apostles of evangelization but as évolués. Or to echo the conceptual framework of the time: as future members of a new elite, close to the colonial state, to whom the General Government held out the prospect of helping shape the territory's fate.

No surprise, then, that contemporary actors within Catholic Action were alarmed by the Voix $d u$ Congolais. As they saw it, the newspaper was not just an alternative communicative space for évolués but also a media-based means of education to which, for the first time, the Catholic missionaries had no direct access. They interpreted the publication as a portent of an increasingly laicist colonial state, as the first step towards a process of elite formation without the missionaries' involvement. Less than two months after the Voix du Congolais first appeared, Georges Six, the highest representative of the Scheut order and apostolic vicar in Léopoldville, received a letter. ${ }^{48} \mathrm{~A}$ concerned missionary in the Congolese hinterland wrote of a recent conversation about the new newspaper. He made an urgent appeal for a form of Catholic Action tailored to the évolués ${ }^{49}$ in order to maintain the Christian moral influence on the elite. The author presented himself as a spokesman for a number of missionaries who had come to the same conclusion when discussing the situation, namely that the évolués had not yet developed to the point where the missions could leave them to themselves or the colonial officials. They regarded the slogan of the Voix du Congolais, "by Congolese, for Congolese," as premature. In fact, as these missionaries saw it, their educational task remained vital - "for Congolese, by missionaries" was how this missionary expressed his preferred approach. ${ }^{50}$

Henceforth the Scheut institutions, which faced major constraints of staffing and finances, were even more insistent that their members must engage personally to influence Congolese school leavers. For example, the head of the Croix $d u$ Congo, Père Liétaert, addressed himself to all mission establishments in the Belgian Congo requesting that they actively support the Catholic media aimed at the évolués. According to Liétaert the Croix du Congo, aligned with Catholic Action, was the only one to offer the évolués a "good read, interesting and instructive."51

48 The roots of the present-day archdiocese of Kinshasa lie in the apostolic vicariate of Léopoldville established on 11 May 1888. Between the mid-1930s and the mid-1950s the vicariate was split into a number of subdivisions. The apostolic vicariate of Léopoldville gained the status of archdiocese in 1959. From 1965 to 1989 Joseph-Albert Malula headed the diocese as the first Congolese archbishop.

49 Letter to Georges Six, provincial bishop of Léopoldville, 3 March 1945, KADOC/O/II/b/9/5. 50 Ibid.

51 Letter from Liétaert to Georges Six, provincial bishop of Léopoldville, 20 September 1947, KADOC/P/II/b/11/12. 
He warned of the growing rivalry within the media triggered by the appearance of government publications such as Voix du Congolais and Etoile-Nyota, which he viewed as a form of ideological competition..$^{52} \mathrm{He}$ also railed against periodicals such as Progrès, published in Elisabethville, ${ }^{53}$ which sought to undermine the missionaries' evangelization. ${ }^{54}$ Liétaert mentioned the project being pursued by the General Government's Section de l'Information pour Indigènes, which planned to publish a French-language weekly for évolués in addition to the Voix du Congolais. The fears expressed by Liétaert in his letter are testimony to the Scheut missionaries' self-image as the guardians of the évolués and the threat to this status posed by the new colonial elite-making policy:

This would be another step in the direction of a neutral and worldly attitude on the part of the évolués' press, as well as towards the state's supplanting of the missions' responsibilities. It would thus be another ace up the sleeve of those who seek to distance our developed Christians from the missionaries and to limit our moral influence on them. ${ }^{55}$

In the end the General Government did not produce this weekly for évolués. One year later, however, the Scheut press launched a competitor to the colonial state's new media. From 1948 on Kongo Ya Sika addressed itself chiefly to the non-literate population, seeking to attract the same target group as the General Government's Nos Images.

State and missionary actors thus vied to exercise an influence on the Congolese elite. Private correspondence between a mission school graduate and his former teacher provides an insight into how this elite related to the changed media situation in the Belgian Congo. Antoine-Marie Mobé, the Congolese party in this exchange of letters, had attained the highest possible level of education by graduating from the grand séminaire in Kabwe in 1944. He opted not to enter the priesthood, however, and instead signed up to become an office assistant within the colonial administration. In his spare time, he promoted the Voix $d u$ Congolais and in 1947 he was named the sixth most successful recruiter of new subscribers. ${ }^{56}$ Over the years he built up a reputation as a diligent and critical correspondent. Mobé maintained private correspondence with Georges Kettel, the seminary's former rector. The latter was mentioned by name - as one of

52 Ibid.

53 On the publisher of Progrès and Echo du Katanga, see Vellut, "Decoster."

54 Articles critical of the missions prompted a lively exchange of letters between high-ranking actors in the Scheut order; Presse hostile, 1948, KADOC/O/II/a/11/18.

55 Letter from Liétaert to Georges Six, 20 September 1947, KADOC/P/II/b/11/12.

56 See A.-R. Bolamba, “Concours de Propagande,” Voix du Congolais no. 24 (March 1948): 121. 
the critics of the colonial state's elite-making - in the aforementioned appeal for help penned by the Scheut missionary. ${ }^{57}$ Likely prompted by his article on the work ethic recently published in the Voix du Congolais, Mobé wrote to Kettel in 1949 regarding his journalistic work. The latter responded with great reserve, despite the fact that Mobé's newspaper article clearly evinced his priestly education. The article had been written in the style of a biblical exegesis and interpreted the cultivation of the garden of Eden as the origin of the work ethic. Mobé thus fit the ideal of an apostle of Catholic Action, one who propagated a Christian way of life beyond the church within his own milieu. Nonetheless, the rector was clearly displeased by the fact that Mobés article had appeared in the Voix $d u$ Congolais. All Kettel could see in the newspaper was a symptom of the advancing decoupling of worldly education from religious schooling and he lamented the évolués' general tendency to abandon their missionary origins. He warned Mobé of the dangers posed by the newspaper, which rarely adopted a "clear Catholic position" and whose articles were characterized by a certain "superficiality." 58 The fact that Kettel also described the Voix $d u$ Congolais as "neutral" may be due to his displeasure at the newspaper's cross-confessional orientation: it integrated authors who had attended Protestant schools and, in its emphasis on the Christian faith, reflected the PSC's ideological opening in Belgium. According to Kettel, as a "good black layman" Mobé ought to try harder to fulfil his obligations: he should remind the évolués who they had to thank for their education, namely the Catholic missionaries. ${ }^{59}$

This example brings out the conflicts of loyalty faced by Congolese authors writing for the colonial state's media in light of the new and overlapping elite institutions. Not only did the colonial state actively address itself to a field it had previously left to the missions, but in the shape of newspapers and associations it also imitated their key instruments. The associated debates, couched in paternalistic terms, bring to mind modern-day parental disputes over the custody of underage children. The missions and the state were convinced that Congolese were not yet mature enough to take responsibility for themselves and still required a guiding hand. The Catholic missionaries continued to play an impor-

57 Kettel was rector in Kabwe, in the province of Kasai, where one of his students was Joseph Kasa-Vubu, later president of independent Congo. He expelled the latter from the seminary in 1939, declaring that he "belonged in the world." Kettel maintained lively correspondence with his former pupils and sent out a circular until at least 1948; letter from Kettel to Mobé, 10 October 1948, private archive Antoine-Marie Mobé.

58 Letter from G. Kettel to Antoine-Marie Mobé, 18 August 1949, private archive Antoine-Marie Mobé.

59 Ibid. 
tant part in the planning and implementation of the colonial state's elite-building measures, whether in a consultative or executive role. The missions were too important to the colonial state to leave them out in the cold and through their engagement the missionaries sought to ensure their influence on former mission school pupils. Congolese authors, meanwhile, made pragmatic use of the opportunities provided them by the elite institutions established concurrently by missionary orders and the colonial state. Author and former seminarian Mobé published in both the Voix du Congolais and the Croix du Congo. For most secondary school graduates, mission schools and the institutions of the colonial state were first and foremost consecutive stages of a career path - of the kind they were predestined to follow within the colonial working world. The évolués-centred "pillar" that the colonial state sought to create among Congolese after 1945 not only possessed - in the shape of missionaries and officials - a number of architects with differing construction plans, but addressed itself to Congolese with ideas of their own.

\section{Controlling reforms and controlling évolués}

Those newspapers that sought to attract the small group of educated Congolese constituted new communicative spaces within the colonial public sphere. ${ }^{60}$ When it comes to both authors and target group this public sphere - as well as other social realms - was segregated into European and African parts. In the larger cities, since the 1910s daily newspapers had been established with a European readership whose print runs remained within the range of 1,000 to 5,000 copies. The Catholic Courrier d'Afrique and Avenir, which was closely associated with the settlers, were published in Léopoldville. The province of Katanga, whose character was profoundly shaped by its resident Europeans, had four newspapers. In the capital Elisabethville the conservative Essor du Congo championed the interests of industrialists and settlers, while the Echo du Katanga, which was published in small numbers, stood out throughout the colonial territory for its anti-clerical and socialist views. Two other newspapers were published in Jadotville and Kolwezi. Settlers in the province of Kivu also had a publication representing them in the shape of Centre Afrique. In the third largest city, Stanleyville, L'Echo du Stan and Le Stanleyvillois competed against each other,

60 For an overview on public spheres and print media in colonial states, see E. Hunter and L. James, "Introduction: Colonial Spheres and the Worlds of Print," Itinerario 44, no. 2 (2020). 
both expressing similar conservative and at times racist views. ${ }^{61}$ While post-war Belgium was characterized by a highly diverse press, covering every political current, with more than fifty opinionated dailies close to the various political parties, ${ }^{62}$ due to harsh press laws the newspapers in the colony had to tread carefully when it came to their coverage of political issues. In addition, the Congolese titles continued to be run paternalistically and published by the colonial state and missionaries. It would be quite wrong to think of the Belgian Congo's colonial public sphere as a realm of well-informed citizens engaging in the free exchange of views as envisaged by Jürgen Habermas. ${ }^{63}$ To what extent, then, did the vernacular elite have a right to a say and the freedom to articulate its views? What kind of control mechanisms were at work ${ }^{64}$

The Charte coloniale laid down strict regulations governing the press landscape. The Belgian colonial government had originally enacted the relevant paragraphs in 1922 in the context of its struggle against the religious healing movements of the Kimbanguists and Kitawala spreading throughout the colony, ${ }^{65}$ and had subsequently modified them on a number of occasions. ${ }^{66}$ The Charte colo-

61 Centre de Recherche et d'Information Socio-Politiques, "La presse quotidienne," 8-10.

62 On the history of the press in Belgium, see J. Servaes, "Concentration and Competition in the Belgian Press," Communications 16, no. 3 (1998).

63 Studies of colonial India emphasize the differences between the colonial public sphere and Jürgen Habermas's bourgeois public sphere as found in Western Europe. Sinha, "Britishness," 492; J. F. Codell, "Introduction. Imperial Co-Histories and the British and Colonial Press," in Imperial Co-Histories. National Identities and the British and Colonial Press, ed. J. F. Codell (Madison: Fairleigh Dickinson University Press, 2003). A study of the educated elite of the Gold Coast draws explicitly on Habermas's notion of the public sphere, though extending it to include associations and recreational institutions; Prais, "Imperial Travelers," 59. For the public sphere in late-colonial Tanzania, see E. Hunter, Political Thought and the Public Sphere in Tanzania. Freedom, Democracy and Citizenship in the Era of Decolonization (Cambridge: Cambridge University Press, 2015). One reason for this may be that until the 1930s the British colonial administration took very little interest in the press and associations of actors categorized as non-political, making little move to interfere in their activities. For an example of this line of argument, see Newell, "Territory of Elites," 229.

64 The following analysis adheres to B. Weisbrod, "Medien als symbolische Form der Massengesellschaft. Die medialen Bedingungen von Öffentlichkeit im 20. Jahrhundert," Historische Anthropologie 9 (2001): 270.

65 For the Kitawala movement, see N. Eggers, "Kitawala in the Congo: religion, politics and healing in 20th-21st century Central Africa” (PhD diss., University of Wisconsin, 2013). On Simon Kimbangu, see J. L. Vellut, Simon Kimbangu 1921: de la prédication a la déportation. Les sources (Brussels: Académie Royale des Sciences d'Outre Mer, 2010).

66 On the modifications made to the press laws, see D. T. Kabiena, "Réglementation de la presse au congo belge: approche systématique," in Aspect de la culture à l'époque coloniale en Afrique centrale. Presse. Archive, ed. M. Quaghebeur (Paris: L'Harmattan, 2008), 52-59. 
niale empowered the General Government to put a stop to the dissemination within the media of ideas it classified as subversive. ${ }^{67}$ Within this framework the import and distribution of publications printed outside the colony were sometimes prohibited by decree. Here the concept of "endangering public order," which was open to interpretation, served the General Government as rationale. ${ }^{68}$ The colonial authorities also reserved the right to carry out far-reaching interventions when it came to the Belgian Congo's press products. The founding of a newspaper or the publishing of any other kind of text on colonial territory required the prior permission of the General Government. This could be withdrawn at any time, at short notice and potentially with permanent effect. Violations of these laws were prosecuted and could result in a six-month prison sentence. ${ }^{69}$ The authorities, then, did not envisage freedom of expression or freedom of the press in the Belgian Congo. Every written word had to be assessed by the colonial government before being made public.

Likewise, the Voix du Congolais provided no counterweight to the colonial state. It was in fact connected with it in a variety of ways. Published by the Service de l'Information pour les Indigènes, a subdivision of the AIMO, in institutional terms it was part of the General Government. The fact that the elite's communicative space was based on a printed medium and required literacy made it easier for the colonial state to exercise control. The idea here was that through this medium the debates and ambitions of the elite would be given a public airing and directed along prescribed paths. The colonial authorities thus kept a close eye on the development of elite's views in the newspaper. While the post of editor-inchief was occupied by a Congolese, Antoine-Roger Bolamba, a European advisor was on hand to supervise his activities. ${ }^{70}$ Articles were printed only once they had been thoroughly checked. Certainly, during the entire period of the existence of the Voix du Congolais, it published many articles written abroad that shone a negative light on colonialism or on Belgian colonial policy. Nonetheless, these

67 Kadima-Nzuji, Littérature, 45.

68 Claessens, La Presse, 9.

69 Ibid., 8-10. An analysis of the press laws in the Belgian Congo is provided by A. Durieux, De la liberté de la presse en droit belge colonial (Brussels: Université Libre de Bruxelles, 1958), 6-28. 70 The colonial government likely intervened in the content of the editorials written by Bolamba. But it would be going too far to state that Congolese were not truly the authors of their articles. This is the claim made in an interview by the Belgian publisher of Paul Lomami-Tshibamba's novels. He asserts that as patron of the Voix du Congolais Domont wrote the editorials rather than Bolamba. But there are no indications of this in the sources; G. A. Deny, "Éditeur de Lomani Tchibamba et de naigiziki. Témoignage recueilli par Emile van Balberghe,” in Papier blanc, encre noire. Cent ans de culture francophone en Afrique centrale (Zaïre, Rwanda, Burundi), eds. M. Quaghebeur and E. Van Balberghe (Brussels: Labor, 1992), 296. 
articles were either abridged or accompanied by a detailed editorial commentary that neutralized their criticisms or "corrected" them on the basis of colonial ideology. ${ }^{71}$ Editor-in-chief Bolamba made it clear on a number of occasions that there was no room in the publication for highly critical contributions sent in anonymously. ${ }^{72}$ Time and again, these interventions provoked claims that the newspaper was a propaganda sheet that let any kind of criticism go by the board. In his editorial Bolamba tried to rebut this notion, repeatedly highlighting the newspaper's success in championing the demands of the Congolese elite. ${ }^{73}$

We cannot be sure of the precise extent to which the articles in the Voix $d u$ Congolais were subject to censorship. The few studies of the newspaper are limited to speculations. Congolese literary scholar Mukala Kadima-Nzuji asserts that the newspaper's writers were free to express their views in the first few issues but that the authorities increasingly intervened from the fifth issue onwards, when the debate on the reform of elite status threatened to get out of hand. ${ }^{74}$ In 1949 the Revue Coloniale Belge thus described freedom of opinion in the Voix $d u$ Congolais in fitting terms: the Service de l'Information et de la Propaganda, the Revue contended, granted Congolese authors "comprehensive freedom of opinion under the discreet tutelage of the relevant authority."75

Nonetheless, the limits to the freedom of expression allowed by the General Government were not set in stone. What one might legitimately criticize, the form this critique might take and who might advance it were governed by a rather arbitrary approach and changed over time. Hence, the Congolese authors who put forward their demands in the Voix $d u$ Congolais or other media walked a fine line. They had to develop a sense of what criticism was acceptable and would evade sanction, operating in a grey zone between the tolerance of the colonial state and illegality. Entering this zone was particularly problematic in those newspapers that were authorized by the General Government but to which, in contrast to the Voix du Congolais, colonial officials had no direct access. Thus, the General Government was presented with displeasing reports from these

71 For instance, in a commentary the editorial team vehemently contradicted the accusation that the colonial administration made too little effort to advance the évolués' interests. "Chronique de la vie indigène," Voix du Congolais no. 20 (November 1947): 877-878.

72 A.-R. Bolamba, "Lettres anonymes et faux rapports," Voix du Congolais no. 15 (May-June 1947).

73 A.-R. Bolamba, "Bilan de quatre années d'effort," Voix du Congolais no. 33 (December 1948). 74 Kadima-Nzuji, "Autour," 20. With reference to anonymous sources, US-American historian Roger Anstey writes that it was not until 1955 that the authorities eased off again; Anstey, "Belgian Rule," 200.

75 C. Goebel, “La presse coloniale Belge et son évolution,” Revue coloniale Belge 100 (December 1949): 772, quoted in Claessens, La Presse, 31. 
media only after they had been published. This put the authors in an ambivalent position: they could submit more critical articles but made themselves vulnerable to attack. For example, when an African author writing in the Croix du Congo in 1954 reported on the arrest of an alleged supporter of the Kitawala movement, whose subversive influence the colonial administration feared, a note was appended to his service record. While the information in his article was correct, his reference to the integrity of the detainee was viewed as an explicit criticism of the colonial administration. ${ }^{76}$ In fine: as guardian of the press the General Government had broad scope for interpretation when assessing articles. Often, whether authors had overstepped the limits of freedom of expression, whether they had put their career - or more - on the line through their journalistic activity, was something they only found out afterwards.

To sound out the limits of freedom of expression in the Voix du Congolais we also have to consider local colonial officials' arbitrary pre-censorship of articles. Among colonial administrators, territorial officials occupied an important position. Situated at the lowest administrative level, they carried out a wide range of tasks; after 1945 these included implementing the colonial state's elite-making policies. As representatives of the colonial state, even in the colony's remotest regions they embodied European rule and they had to enforce this claim to hegemony vis-à-vis the local population. In a novel, Malian writer Amadou Hampâté Bâ characterizes the territorial administrators as "gods of the bush" in light of their substantial powers. ${ }^{77}$ Through the quotidian display and performance of hierarchical difference between Africans and Europeans, these officials put a face on the colonial order.

Many of the Congolese authors writing in the Voix $d u$ Congolais worked as office assistants in the local colonial administrative system. The colonial hierarchy was reflected in the workplace: in administrative offices - but in every other part of the working world as well - African clerks were always subordinate to a European superior whose instructions they were required to follow. ${ }^{78}$ They typed up letters as instructed; their personal views were not required. The territorial officials perceived it as a threat to their power that their office assistants could now forge a direct connection with the colonial government as contributors to the

76 Correspondence between various offices of the colonial administration and the Prescobel news agency concerning a sensitive article in the Croix du Congo (December 1953-April 1954), $\mathrm{AA} / \mathrm{GG} / 5418$.

77 A. Hampâté Bâ, L'étrange destin de Wangrin (Paris: Union générale d'éditions, 1973).

78 On white-collar work in colonial Africa, see D. van den Bersselaar, "White-Collar Workers," in General Labour History of Africa. Workers, Employers and Governments, $20^{\text {th }}-21^{\text {st }}$ Centuries, eds. Stefano Bellucci and Andreas Eckert (Suffolk: Boydell \& Brewer, 2019). 
Voix du Congolais and potentially bring political pressure to bear. Time and again the vernacular elite called on the colonial government to make good on its promises, causing clashes with the local agents of colonial power. It was above all local officials who resisted the new colonial policy emanating from Léopoldville and Brussels, convinced the colonial order was at risk. ${ }^{79}$ The territorial officials' intervention in the work of Congolese authors provides an initial example of the way in which conflicts between various actors within the Belgian colonial state were played out at the expense of the new collaborative elite.

Yet in the main it was the territorial officials that the Section de l'Information pour Indigènes tasked with promoting the newspaper. Particularly in remote regions, the newspaper's success depended on their support. In January 1945 they received a package containing several copies of the newspaper. In an accompanying letter the patron of the Voix du Congolais, Jean-Paul Quix, requested that they distribute sample copies among their administrative unit's évolués. In addition, they were supposed to encourage their Congolese office assistants to ask their friends to subscribe. Above all, the officials were to urge the "most capable of the évolués" to contribute to the newspaper. ${ }^{80}$

It is impossible to gauge the extent to which the local colonial officials did as they were asked. But we do know that at times they overstepped the limits of their authority and sought to influence the content of articles. The sources reveal a number of cases in which colonial officials insisted on perusing articles before they were sent to Léopoldville. ${ }^{81}$ This tendency for Congolese authors' superiors to monitor and supervise their journalistic activities was particularly marked outside the cities. ${ }^{82}$ The General Government learned of this practice and as the publisher it tried to counter any wilful pre-censorship by its officials. The provincial governors were informed that local colonial officials were authorized neither to rewrite articles nor to prohibit their dispatch. Authors were not to be discouraged through the censorship of their work. The true role of the Voix du Congolais must not be undermined: "To give the Congolese an outlet for their criticisms and de-

79 The "relatively high degree of independence from the centre of power enjoyed by the local administrative officials" is characteristic of colonial rule and is mentioned in a number of studies on German and French colonies; Eckert, Herrschen, 36.

80 Letter from Jean-Paul Quix to a number of territorial officials, 6 January 1945, AA/GG/10384. 81 Letter from Paul Ipupa to territorial administrators in Coquilhatville, 5 April 1945, AA/GG/ 10384.

82 A reader's letter in the Voix du Congolais from an administrative worker highlighted the fact that outside the cities the évolués were generally controlled more closely by the colonial officials: "In the interior a closer eye is kept on our conduct than in the major [urban] centres." “Chronique de la vie indigène,” Voix du Congolais no. 70 (January 1952): 35. 
sires, and thus to help [the authorities] discover what the indigenous population is saying and thinking." ${ }^{83}$ The colonial government thus expected the newspaper to enhance its knowledge, to provide it with an unclouded view of the elite's desires and complaints. As a print medium, the Voix du Congolais was supposed to provide a new form of colonial knowledge from which colonial rule could take its lead. ${ }^{84}$ This medium was not only supposed to yield information about the new collaborative elite, but also to illuminate their views on the progress of developmental colonialism - and thus on the work of the local colonial officials.

Hence, although authors were well advised to refrain from articulating general critiques of colonialism in the Voix du Congolais, they knew how to use the newspaper as a forum for their interests. The elite's new communicative space was not an uncritical one. Authors made interventions in their social and cultural affairs. The scope for critique was delimited by the General Government in Léopoldville, which had in turn to gear itself towards the political programmes emanating from the Colonial Ministry in Brussels. The limits of the sayable thus expanded and contracted in alignment with the prevailing political agenda. The authorities wanted authors to express their views whenever reformist projects came up against local resistance. The authors, meanwhile, prompted corrections, here and there, to the colonial project - particularly when everyday reality was out of sync with the promises inherent in official policy.

Whether it was photographs of newly built houses produced by the statesponsored building programme, of new school buildings and hospitals, or reports on the amicable encounter between Europeans and Congolese: precisely because the Voix du Congolais communicated an ideal-typical image of the Belgian Congo it set the standard by which readers and authors could assess their own lifeworlds. Only rarely did representations of the model colony bear comparison with actual living conditions. The Voix $d u$ Congolais was the medium through which this discrepancy was made public - and brought to the attention of the colonial authorities.

That the Voix $d u$ Congolais played a key role as intermediary within the processes of colonial reform is evident in the complaints put forward by the évolués of Matadi, about which the newspaper carried several reports in 1952 and $1953 .{ }^{85}$

83 Letter from the governor general to the governor of Équateur province, 13 December 1955, AA/GG/6055.

84 For an introduction to the complex relationship between knowledge and power within European colonial rule, see Conrad, Kolonialgeschichte, 79-84.

85 These appeared in the "Chronique de la vie indigène" in the following issues: Voix $d u$ Congolais no. 77 (August 1952): 487-488; Voix du Congolais no. 79 (October 1952): 625-626; Voix du Congolais no. 83 (February 1953): 123; Voix du Congolais no. 84 (March 1953): 189-190; Voix du 
The point of departure was an article in a section of the newspaper called the "Chronicle of Indigenous Life," in which critical reports on colonial realities often appeared. The editors frequently anonymized these articles, which were accompanied by a request to the relevant state authorities to follow up on the issues raised. This was the case when it came to complaints emerging from the port city of Matadi, whose authors presented themselves as "certain representatives of the Congolese elite." 86 Their spokesman drew attention to the everyday vexations of life in Matadi's African quarter. He bewailed the education and work ethic of the midwives in the hospital for Congolese, vented his frustration at the unfavourable location of the cemetery, which was outside the residential area, railed against the ban on domestic vigils for those who had died in hospital - and expressed his indignation at the unsanitary state of the public toilets. ${ }^{87}$ This critique took direct aim at the failure to implement promised colonial reforms. Since 1949 the Ten-Year Plan, the centrepiece of Belgian developmental colonialism, had pledged to develop the medical and urban infrastructure for Congolese. European ideas about sanitation and medicine, such as hospital births, were only partially embraced within society, but constituted a distinguishing cultural hallmark for those évolués keen to assimilate, ${ }^{88}$ who now demanded that the colonial government bring about the conditions envisaged in the TenYear Plan. In other words, the complaints emanating from Matadi were being put forward by members of the Congolese elite, who took the discourse of modernization literally.

Complaints like this were often to be seen in the Voix du Congolais. The report from Matadi, however, is one of the few cases for which we also have access to correspondence produced by the colonial administration, which reveals that the authorities made a serious effort to get to the bottom of such matters. From the desk of the editor-in-chief of the Voix du Congolais, the complaints from Matadi were fed into the hierarchical channels of the colonial bureaucracy. Before the article had even been published, Bolamba had sent a letter to the provincial governor in Léopoldville asking for clarification. ${ }^{89}$ The governor in turn

Congolais no. 85 (April 1953): 261-262; Voix du Congolais no. 86 (May 1953): 481-485; Voix du Congolais no. 90 (September 1953): 625-626.

86 “Chronique de la vie indigène,” Voix du Congolais no. 77 (August 1952): 487-488.

87 Ibid.

88 Hunt, "Le Bébé,” 428; N. R. Hunt, A Colonial Lexicon, 13; Mianda, “Colonialism,” 154.

89 Letter from Antoine-Roger Bolamba to the governor of Léopoldville province, 26 July 1952, ARNACO/AIMO/73CC/82/244. 
tasked his subordinate administrative officials with verifying and resolving the problems raised. ${ }^{90}$

The district commissioner and territorial administrator then gave the provincial governor assurances that the shortcomings had long since been reported at the local level and the relevant institutions informed. Further, they questioned the credibility and validity of the complaints and raised suspicions about who might be behind the anonymous article. ${ }^{91}$ In a letter to the General Government the provincial governor subsequently denied all responsibility, describing the article as "unfounded and unreasonable."92 The governor general responded promptly with a sharp rebuke, ${ }^{93}$ reproaching the provincial governor and his staff for having provoked these public complaints by failing to inform the population about measures intended to improve the situation. ${ }^{94}$ The governor general was not concerned about the authors of the article, who were known to the Voix du Congolais and may have been granted anonymity for their own protection. The colonial government was far more concerned about its officials' deficient efforts to implement the Ten-Year Plan - failings that had been laid bare by the Voix du Congolais.

In the governor general's letter to his subordinate officials, we find a sentence that provides an insight into how the Voix du Congolais dealt with the criticism submitted to it and the role the colonial government allocated to the newspaper as a result:

90 Letter from the governor of Léopoldville province to the district commissioner of Bas-Congo, 7 August 1952, ARNACO/AIMO/73CC/82/244. The relevant file includes several exchanges of letters referring to the articles in a single issue of the Voix $d u$ Congolais. One can only imagine the scale of the correspondence triggered by the total of 165 issues. Presumably, the complaints were evaluated differently, according to region or date for example. In the case discussed here, in any event, Bolamba reiterated to the governor of Léopoldville province his request that the grievances be addressed by highlighting Matadi's importance as the largest port city in the Belgian Congo. Situated on the Congo River and providing access to the Atlantic, Matadi was the key hub for trade, transport and communication with Belgium. Here goods arriving from the navigable mouth of the Congo River were transferred to rail and transported further via the Matadi-Léopoldville railway line.

91 Letter from the territorial official in Matadi to the district commissioner of Bas-Congo, $15 \mathrm{Au}$ gust 1952 and 18 August 1952; letter from the district commissioner of Bas-Congo to the governor of Léopoldville province, 28 August 1952, ARNACO/AIMO/73CC/82/244.

92 Letter from the governor of Léopoldville province to the General Government, 16 September 1952, ARNACO/AIMO/73CC/82/244.

93 Letter from the governor general to the governor of Léopoldville province, 8 October 1952, ARNACO/AIMO/73CC/82/244.

94 See ibid. 
I feel I must remind you that the statutes of the Voix $d u$ Congolais grant it effective freedom of opinion. Even if the official responsible for the indigenous press manages to prompt the articles' authors to tone down certain statements, he cannot rid the newspaper of all criticism submitted by its correspondents. Otherwise, it would lose its raison d'etre. ${ }^{95}$

For the General Government, the point of the newspaper was to provide the Congolese population with a platform for complaints. Along with its correspondents, the publication served as a seismograph gauging sentiment among the vernacular elite and the colony's state of development. The Voix du Congolais established media-based communication between the elite spokesmen of the population and the centre of political power in the Belgian Congo, a form of communication that left out the local colonial officials. This furnished authors and contributors with unprecedented opportunities to articulate their views. They could work on the premise that the colonial government would take their critique seriously if it deemed it legitimate, instructing its administrative officials to try to find solutions.

Because of this new voice of the Congolese elite, the European superiors, whether administrators or firm owners, could no longer do as they pleased. Now they were under observation and their misconduct was made public for the most part by their own clerks. If a territorial administrator saw his office assistant sitting at the typewriter, he could no longer be sure whether he was merely typing up the letter he had just dictated or giving vent to his grievances about local living conditions. This was a key factor motivating these officials' efforts to control correspondents' activities.

The General Government's elite newspaper thus entailed a reciprocal control function. The European authorities kept a sharp eye on the Congolese elite, just as the elite kept a close watch on the colonial administration's European representatives. When it came to the oft-criticized public toilets in the African quarter of Matadi, ${ }^{96}$ after further calls for action had been published in the Voix $d u$ Congolais a correspondent reported that the colonial administration had finally arranged to have them cleaned several times a day. ${ }^{97}$

The tensions between territorial officials and the General Government triggered by the African elite's new opportunities to have its say in the Voix du Congolais also became apparent when its editors made trips to various parts of the colony. The promises of colonial reform emanating from the capital city of Léopoldville not only made it to the provinces through newspapers but also through

95 Ibid.

96 “Chronique de la vie indigène,” Voix du Congolais no. 84 (March 1953): 189-190.

97 L'Echotier, "Reportage à Matadi," Voix du Congolais no. 86 (May 1953): 484-485. 


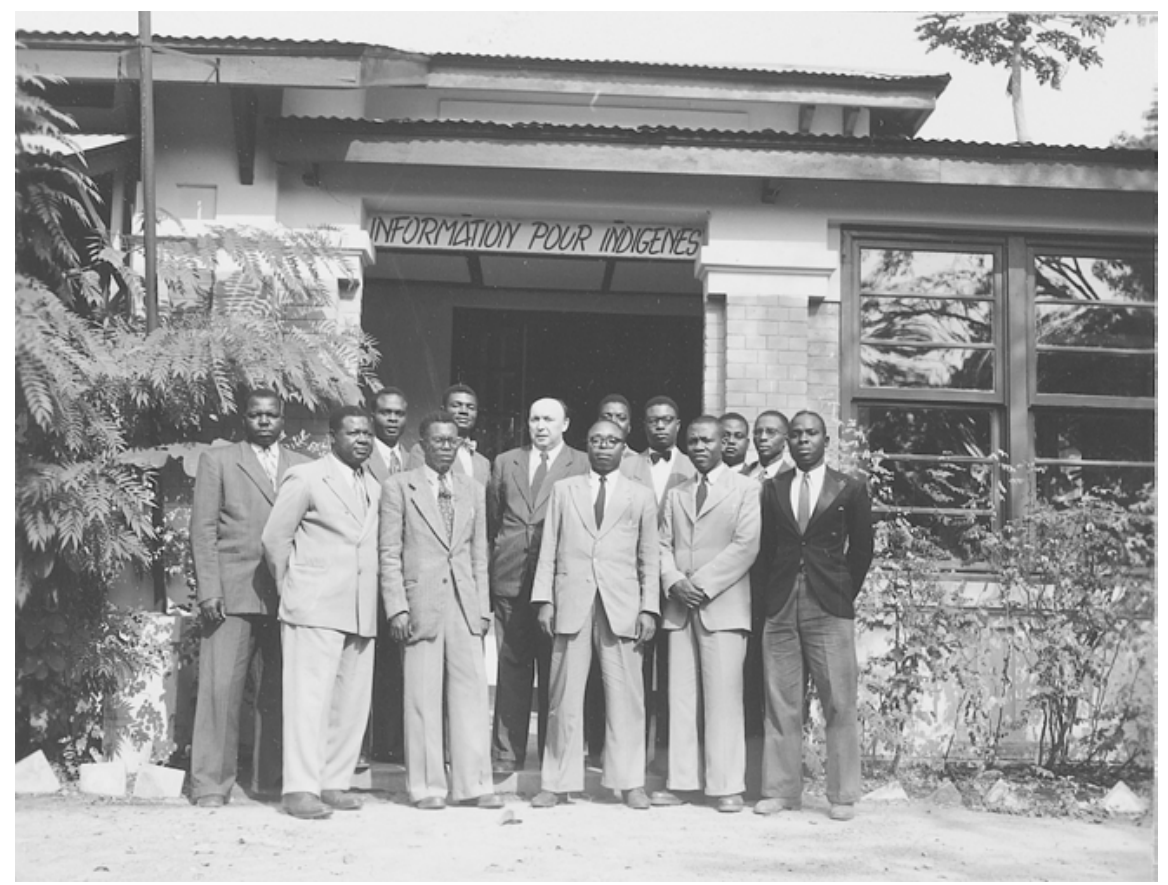

Fig. 6: Advisory Board of the Voix du Congolais with Jean-Marie Domont, head of the Section de l'Information pour Indigènes (centre). Of the individuals mentioned in the present book those appearing here are: Eugène Kabamba (second from left), Jean Bolikango (third from left), Etienne Ngandu (ninth from left), Jacques Massa (tenth from left) and Jean-Pierre Dericoyard (eleventh from left).

visits made by the staff of the Voix du Congolais - often to the territorial officials' chagrin.

The newspaper's core editorial staff did a considerable amount of traveling, a privilege denied other Congolese by rigid regulations on freedom of movement. ${ }^{98}$ Whether on official business or for personal reasons, the authors writing for the Voix du Congolais used their sojourns to give talks at associations and to visit their correspondents and old schoolmates. Later they published articles in the Voix du Congolais on their observations and experiences, on the challenges

98 If Congolese wished to travel outside the territory in which they were officially registered they needed permission from the territorial administrator, a "relocation permit" and a "health visa." The form they had to fill in included information on their destination, route and the length of their trip. Travelers who failed to obtain the necessary documents were likely to be convicted of vagrancy. See Mutamba-Makombo, "Les évolués," 100. 
and insights arising from their journeys, thus providing readers with the first reports written by Africans on the various parts of the colony.

As the newspaper's editor-in-chief, Bolamba spent a particularly large amount of time on the road. ${ }^{99}$ At times his many travelogues read like a blend of inspection report and promotional tour for colonial reforms. In October 1948 he made a 90-minute stop in Lisala, which was predestined for high-profile through-traffic as an important trading site on the Congo River located between the cities of Mbandaka and Stanleyville. As it happens, the governor general had made a stopover there shortly before Bolamba visited the local évolués' association. When the mail boat Bolamba was traveling on reached the port of Lisala one day late, a car sent by the local colonial administration was there to meet him and take him to the association known as the Cercle Ryckmans. ${ }^{100}$ This group, named for the former governor general, came under the purview of the territorial administrator and submitted regular reports on its activities to the Voix du Congolais. ${ }^{101}$ On behalf of the Cercle Ryckmans, club secretary Paul Mongbanga welcomed their visitor from Léopoldville as a "pioneer of development."102 In his speech Bolamba defended the Belgian colonial project against those who saw it as a mere attempt to exploit. According to Bolamba, this criticism only demonstrated the envy of those living in the neighbouring colonies. At the end of the day, he contended, the Belgians had done more to develop the colony in 50 years than other European countries had done in their possessions in two or three centuries. ${ }^{103}$ He encouraged those present to get involved in the Voix $d u$ Congolais, which he described as compulsory reading for every Congolese: “We are our guardians' concern. Let us open our hearts to them and if something displeases us let us tell them about it."104

That morning in Lisala Bolamba underlined the newspaper's role as the champion of Congolese interests with considerable ostentation. He took out his notebook and invited the association members to tell him about their wishes and grievances, which he noted down. Office assistants, teachers and tradesmen complained about their low wages, while employees of the colonial administra-

99 Bolamba wrote several dozen reports on his journeys. Tellingly, a book containing a selection of his texts bears the title Carnets de voyage. See A. R. Bolamba and C. Cassiau-Haurie, Carnets de voyage. Congo-Belgique 1945-1959 (Paris: L'Harmattan, 2009).

100 Report by Paul Mongbanga on Bolamba's visit, 10 October 1948, AA/GG/7921.

101 By October 1948 nine such reports had appeared in the section dedicated to associations' activities.

102 Paul Mongbanga's speech of welcome, 8 October 1948, AA/GG/7921.

103 Report by Paul Mongbanga on Bolamba's visit, 10 October 1948, AA/GG/7921.

104 Ibid. 
tion assailed the fact that it took five years for them to be granted holidays. Others expressed criticism of the poor treatment they received from their European superiors and lamented the lack of medical facilities. ${ }^{105}$ These grievances cropped up frequently in the pages of the Voix du Congolais, with the colonial government typically pledging action to resolve them.

The fact that the territorial official responsible for Lisala, who was also the Cercle Ryckmans's European adviser, was absent from the meeting was not without consequence. ${ }^{106} \mathrm{~A}$ few days later he instructed Pierre Mongbanga, who was not only the secretary of the Cercle Ryckmans but also his office assistant, to provide him with a written report on the meeting. Because Mongbanga was responsible for producing a record of Bolamba's stay, in a letter from the territorial official he was admonished and gruffly reminded that the meeting should not have taken place in his absence, as the representative of the local colonial authority. ${ }^{107}$ While the territorial official explained that an appointment with a legal official had kept him from attending, we are left with the impression that he had gone out of his way to prevent Bolamba's meeting with the members of the Cercle Ryckmans.

If so, this was no isolated case. In his travel reports, later published in the Voix du Congolais, Bolamba complained of the lack of support he had received from the local colonial administration in many places. ${ }^{108}$ That local colonial officials in the hinterland were far from thrilled to see members of the elite from Léopoldville is evident in another article in the Voix du Congolais. Here an anonymous author complained that the territorial administrators in the colony's interior treated évolués from the capital as if they were "agents of Moscow." 109 Despite the fact that no such cases had been documented, from 1947 on the General Government urged its territorial officials to report communist sympathizers among the population. ${ }^{110}$ As a result of this anti-communist hysteria the selfconfident section of the elite was interpreted as subversive. The popularity of this perspective among colonial officials in remote areas, where educated Congolese were the exception, was a trans-imperial phenomenon. ${ }^{111}$

105 Ibid.

106 Notes by the territorial administrator of Lisala on Bolamba's visit, n.d., AA/GG/7921. It was not possible to make out the name of the territorial administrator in the documents.

107 Ibid.

108 Bolamba, "Impressions de voyage," Voix du Congolais no. 47 (June 1950): 99-102.

109 “Chronique de la vie indigène,” Voix du Congolais no. 39 (June 1949): 244.

110 See Gijs, Le pouvoir, 161.

111 On Portuguese Angola, for example, see Keese, Living, 106. 
In any case, when it came to Bolamba's visit, what particularly stuck in the craw of the territorial official in Lisala was the fact that the association members were able to openly articulate their criticisms of local shortcomings. In his report Mongbanga had listed the individual criticisms put forward by association members along with their names. ${ }^{112}$ That he included his own critique in this report, which he submitted to his superior, shows that he was unaware of the document's explosive character. Mongbanga had informed Bolamba that the medical establishments were doing a poor job of looking after the Congolese population and that some évolués had to put up with insults from their superiors. The territorial official, however, interpreted Mongbanga's critique as an "attack on the local health service." 113 What Bolamba, as an envoy of the colonial government, had presented to the members of the Cercle Ryckmans as a legitimate expression of opinion, the local territorial official regarded as hostility towards colonial authority. This incident shows that the elite's new opportunities to articulate their views were not immediately regarded as legitimate or acceptable in every quarter and that the degree to which they could make use of these opportunities often depended on the local colonial authorities.

Reading between the lines, in Mongbanga's reply to the territorial official we can discern a learning process that the vernacular elite had to undergo as a critical companion to colonial reforms. His letter is characterized by a semantic balancing act between loyalty and self-assertion that the évolués' spokesmen had to master vis-à-vis European authorities and superiors. On the one hand Mongbanga wrote that Bolamba should indeed have made his presence known to the local authorities. But this had simply not been possible. ${ }^{114}$ On the other, he contended, his critique had not been an attack but merely "an account of the facts." 115 Mongbanga deftly toned down his bold response, however, by availing himself of the colonial cliche that the Congolese had a poor command of the French language: "I admit, of course, that my instruction in the French language is insufficient. I would request that you amend my phrasing and understand it as appropriate."116

Well aware of the risks of expressing one's opinion, the elite learned to envelop their criticisms in a cloak of circumspection - not just in their articles but also when in direct contact with those local authorities that, in practice, contra-

112 Report by Paul Mongbanga on Bolamba's visit, 10 October 1948, AA/GG/7921.

113 Notes by the territorial official of Lisala on Bolamba's visit, n.d., AA/GG/7921.

114 Mongbanga's response to the criticism of the territorial administrator of Lisala, n.d., AA/ GG/7921.

115 Ibid.

116 Ibid. Apart from getting one phrase wrong ("dans le bon terme" rather than "dans le bon sens du terme"), however, his French was free of error. 
dicted the rhetoric of colonial development cultivated by the General Government. The authors were thus skating on thin ice when they used the Voix du Congolais as a forum for their demands. Yet it was not just institutionalized control by the General Government and unauthorized interventions by territorial officials that influenced the limits of the sayable, but also authors' self-censorship. Many took care not to be overly critical for fear of possible punishments and penalties. It is difficult to demonstrate the practice of self-censorship with reference to historical sources: we can analyse published articles but not texts abandoned due to caution or the revisions made to those ultimately published.

To sum up, in the wake of the post-1945 reforms the Belgian colonial government decisively expanded the Congolese elite's space of medial communication. But the tight limits on freedom of expression and the capacity to have one say reflected the official policy of the colonial government in Brussels and Léopoldville, and it was within this narrow field of action that Congolese authors' media interventions occurred. At times they came into conflict with representatives of the colonial administration who felt that their authority was threatened by the évolués' media-based scrutiny. Even if the elite public sphere could, to a certain extent, shine a light on the implementation of colonial rule, this elite realm was subject to control as well. The Voix du Congolais thus epitomized the ambivalences of colonial development after 1945.

Controls imposed by the colonial government, unauthorized interventions by local officials in the production of articles, and self-censorship in order to avert possible sanctions: authors held back, camouflaged their criticisms, and put forward their demands in a measured and polite way. While the voice of Congolese authors may have appeared too strident to some Europeans in the colony, ${ }^{117}$ in reality they tended to be reticent and intimidated.

But it would be too simple to comprehend the Voix $d u$ Congolais as a colonial ventriloquist, with disempowered Congolese in the role of dummy. Certainly, the newspaper disseminated state propaganda acclaiming developmental colonialism, but the elite took this colonial discourse of progress and modernization literally. Authors used colonial propaganda to pursue their own agenda. They insisted on their points of view and demanded, with a degree of success, that the colonial authorities implement their promised reforms. In French and British colonies, it was African labour movements and politicians that articulated their demands in the official language of post-war reforms to wrest concessions from

117 Article in the Essor du Congo of 6 May 1945, quoted in Voix du Congolais no. 3 (May-June 1945): 92. 
the colonial government. ${ }^{118}$ In the apolitical Belgian Congo, which had virtually no trades unions, it was authors that took on this role as they made their voices heard in the press. The Voix $d u$ Congolais created a communicative space in which the colonial government, colonial officials and Congolese elites negotiated colonial change through a highly contentious process. ${ }^{119}$ In the Belgian Congo after 1945 the vernacular elite's legal equality with Europeans was a particularly contested topic that rocked the foundations of the colonial order. The concepts évolués and "African elite" developed into tendentious ones within the public debate on the reform of the legal status of Congolese. In the Voix du Congolais, which played a crucial role in the genesis of the évolués' status, these concepts exemplified the legitimate "languages of claim-making and counter claim-making." 120

118 See Cooper, Decolonization, 2-3, 10-11.

119 Ute Frevert is quite right to refer to a communicative space that "provides a broad arsenal of rituals, ceremonies and symbolic practices that reflect prevailing or desired political conditions but also (and to an even greater extent) help to produce and transform them." U. Frevert, "Neue Politikgeschichte. Konzepte und Herausforderungen," in Neue Politikgeschichte: Perspektiven einer historischen Politikforschung, eds. U. Frevert and H.-G. Haupt (Frankfurt am Main: Campus, 2005), 16.

120 F. Cooper, Colonialism in Question, 24. 